\title{
Practical Movements: Kinetic Rituals in the Ancient Western Mediterranean
}

\author{
Mireia López-Bertran
}

Ministerio de Educación y Cultura/FECYT, Madrid, Spain and School of Humanities, University of Glasgow, Glasgow G12 8QQ, Scotland, $U K$

E-mail: mireia_lopez@hotmail.com

\begin{abstract}
Scholars have studied the long-distance movements of people and goods in Phoenician and Punic society between the eighth and the second centuries $B C$ in considerable depth. However, little attention has been paid to travelling, walking and sailing as common activities in their daily lives. It was through living in and moving through landscapes and seascapes that people constructed their sense of place. Sacred places may have been nodal points in these settings and everyday movements may well have become ritualized. This article develops the idea that journeys to shrines might be considered as pilgrimages and stresses the kinetic aspect of these practices. I suggest that trips to shrines were important elements in the ritualization of movements and landscapes. Equally, the movements performed by visitors both inside and outside the shrine have the same significance and are essential to achieving what are known as metaphoric movements. We explore these ideas in two settings, the Phoenician-Punic Western Mediterranean shrines in the cave of Es Culleram (Ibiza, Balearic Islands, Spain) and Gorham's cave (Gibraltar, United Kingdom), which date from the period between the eighth and the second centuries $B C$.
\end{abstract}

Keywords: Phoenician, Punic, rituals, pilgrimage, embodiment, movement

\section{Introduction}

Archaeologists have studied journeys and movements of people in the ancient Mediterranean from many different viewpoints. Traditionally, long-distance travel has been attributed to economic activities, mainly trade (Helms 1988: 5; Cummings and Johnston 2007: 1). Others, however, have suggested that mobility is an essential feature of Mediterranean societies in everyday contexts (Knapp and van Dommelen 2010) and that travelling had a social and symbolic meaning that could transform and define one's social identity (Cummings and Johnston 2007).

A strategy for examining the question of movement in ancient Mediterranean societies is the search for and reconstruction of the paths and routes along which they travelled (Gibson 2007). But this approach is hampered by the ephemeral character of these routes and the radical changes in the landscape over the last two millennia. Another option is the study of the movement of goods. Focusing on materials per se, however, hides the complexity of other dimensions of mobility: more specifically, how and why people move and what transformations are carried out (Kador 2007: 42).

This article aims to shed light on a particular aspect of mobility: pilgrimages to shrines in the ancient western Mediterranean. I will focus on two cave-shrines that are part of Phoenician and Punic landscapes and seascapes: Es Culleram (Ibiza, Balearic Islands, Spain) and 
Gorham's cave (Gibraltar, United Kingdom). My goal is threefold: first, I explore the concept of sacred journeys or pilgrimages; second, I try to go beyond the argument of long-distance travel and stress the local and everyday aspect of mobility. Finally, by analysing the caves, I show how movements around familiar landscapes and seascapes were not neutral experiences, but ones that transformed the space, the travellers themselves and their material culture.

\section{Movements, Pilgrimages and Kinetic Rituals}

Studies of movements in Phoenician and Punic scholarship have traditionally focused on longdistance journeys: not surprisingly, as the Phoenicians and Punic people were renowned seafarers who developed a sophisticated system of navigation through the Mediterranean and the Atlantic. These features have been highlighted by scholars studying the Phoenician trade diaspora from the eastern Mediterranean to the Atlantic (from the mid-9th century to the 6th century вс), and the subsequent Punic presence in the western Mediterranean and the Atlantic as well (6th-2nd centuries BC). Research has focused mainly on the navigation routes, while the technical aspects of boats and sailing have been analysed in great detail (Costa and Fernández 1998; Medas 2000; Peña 2004). Briefly, these scholars have defined Phoenician navigation mainly as a combination of cabotage-for short trips-and deep sea navigation, mostly at night, with several ports of call across the Mediterranean (Aubet 2009: 181-86).

The narratives underlying this avenue of research draw mainly on the idea that moving is linked to colonization and that travellers were already familiar with their destinations. This view has also been influenced by the written sources: from Homer to the voyage of Hanno, classical authors focused on long-distance voyages and stressed the adventure and the danger (Helms 1988). Such perspectives, however, disregard the connections between people and landscapes as well as the everyday aspect of travelling; its definition as a disembodied activity only carried out for commercial and economic reasons ignores the fact that people encountered new worlds to which they were obliged to adapt, and that diasporas may well have been accompanied by a feeling of disjointedness rather than by any sense of arrival (Cummings and Johnston 2007: 1). Those studies also overlook the possibility that navigation may well have been the most common form of movement for everyday activities such as fishing or communication between different settlements; they ignore the construction of seascapes and landscapes that these trips would have entailed. It is my intention to go beyond these definitions and look for the connections between travelling, landscapes and seascapes and how people ritualized their movements along these routes.

The cave shrines I deal with in this paper were not permanently inhabited, as noted in more detail below. People who visited the shrines did so deliberately to make pilgrimages. But instead of focusing solely on the religious connotations and the immaterial features of this term, I use the definition of Coleman and Eade (2004: 1), which understands pilgrimages as kinetic rituals in which the essential thing to analyse is movement in a broad sense. This definition stresses the materiality of movements and expands their interpretation, no longer linking pilgrimages exclusively with trips to the shrines. Here I focus on the kinetic aspects of travelling in a broad sense, considering not just the idea of displacement, but the rest of the activities carried out during the practice of rituals as well-for example, walking and eating.

Following on from Coleman and Eade (2004: 15), I consider three perspectives to study the movements involved in the visits to the cave-shrines. First, the performative features of movement: I will show how the journeys to the shrines were essential not only in the transformation of the landscape and the seascape into familiar settings, but also in their ritualiza- 
tion. Second, I stress the embodied features of movement, and in particular the movements to and inside the caves. Finally, I emphasize the metaphorical dimension of movement. Visiting the shrines implies not only physical but also symbolic movement, in order to engage with otherworldly beings.

My approach to these 'kinetic rituals' is also based on the concept of ritualization (Bell 1992: 88-93). Ritualization is useful because it avoids the difficulties that archaeologists face in defining rituals (Kyriakidis 2007: 289; Insoll 2004: $10)$. It is generally agreed that the traditional definition of rituals - as irrational, unusual or odd activities clearly divorced from everyday actions-is unhelpful (Brück 1999; Bradley 2005).

Bearing in mind the insights of Bourdieu's Theory of Practice (1977), rituals have to be studied in terms of practices. This vision stresses the materiality of rites: it emphasizes the need to interpret them in terms of activities and to take into account to what extent and in what ways they differ from other practices. This is highly significant because in many cases (such as the study presented here), the materials associated with ritual performances are the same as the ones found in everyday contexts (Kyriakidis 2007: 16).

The way to distinguish between the two spheres is to consider rituals as types of behaviour that differ from others because of what they do and how they do it. Thus ritualization focuses on the idea that daily practices and rituals are closely connected; ritual practices can be common actions which, for particular reasons, are intentionally overemphasized through the formality of the activities, their invariance, and the care taken in their performance. Another important issue that arises in considering the materiality of rituals is their connection with bodies and senses (Skeates 2010; Hamilakis et al. 2002). Rituals are embodied activities, physical actions that heighten the exploitation of the senses. In this study, I examine the connections between rituals and everyday activities in the two cave-shrines, at the same time highlighting the importance of the senses.

\section{Cave-Shrines as Liminal Areas}

The use of caves as shrines is widespread across the Mediterranean. Caves tend to be hidden, isolated and hard to reach; inside the space is restricted and usually dark. These features make caves appropriate ritual spaces. They have been interpreted as liminal areas between different worlds, ideal for people to engage with divinities and supernatural forces, or to perform fertility cults or rites of passage (Whitehouse 1992; 2007; Bradley 2002: 27-28). Because of these features, caves have been studied as multi-sensory environments where the exploitation of the senses is strongly modified when people dwell, visit or perform rituals in them. In order to have an embodied idea of the human experiences in caves, aspects such as access, sound, strangeness, secrecy, fear and sensory deprivation should all be considered (Skeates 2007: 90-91).

The existence of cave-shrines in Phoenician and Punic societies has been extensively recorded. There are cave shrines throughout the Mediterranean, from Lebanon to Gibraltar (Gómez Bellard and Vidal González 2000). Traditionally they have been studied as rural shrines that would have been visited mainly by seafarers. Their maritime dimension results from their location in strategic sailing points and their natural features, which make them easy for seafarers to spot. It has been suggested that the cave shrines were used by sailors in rituals to ensure safe journeys and that these practices expressed a popular and private religion (Gómez Bellard and Vidal González 2000: 122).

Another explanation has been proposed for the religious character of the caves (Vella 1998: $394-411 ; 2005)$. The argument is based on a phenomenological perspective that stresses the importance of dwelling in the landscape and the seascape. The focus is not on navigation 
but on way-finding, a term that refers to sea voyages made without the use of modern cartographic maps (Ingold 2000). In way-finding, seafarers do not travel from one abstract point to another, as indicated on maps, but move through different places and landmarks creating and memorizing itineraries of environmental features (Vella 2005: 49). In their experience of the seascape, seafarers give significant meanings to landmarks that symbolize clear references during voyages, a practice that explains their sacralization. Thus, caves became shrines in connection with the sacralization of the broader landmarks in which they are located and not in and of themselves.

\section{Case Studies: Es Culleram and Gorham's Cave}

Here I consider two Phoenician and Punic caves. Es Culleram is a cave-sanctuary on the southern hillside of the Sant Vicent valley in
Ibiza (Figure 1). Oriented southeast, it is $150 \mathrm{~m}$ above sea level and only $1.5 \mathrm{~km}$ from the beach; it offers an excellent view of the sea (Gómez Bellard et al. 2005: 33).

The cave has been altered since ancient times, first when it was transformed into a shrine and later as a result of demolition work during the twentieth century. Nonetheless it is clear that Es Culleram exhibits a tripartite organization of space (Figure 2). First, there is an artificial quadrangular hall, created by two walls built into the stone of the cave and partially covered by a clay and cane roof; second, a large area with a very low ceiling (between 1.5-2 m) covered by a partially destroyed stone vault comprises four different areas or rooms presenting an irregular profile and a large number of stalagmites; finally, the holy of holies is formed by an oval room 5 $\mathrm{m}$ high. There is also a rectangular cistern at the entrance of the cave, directly excavated in the

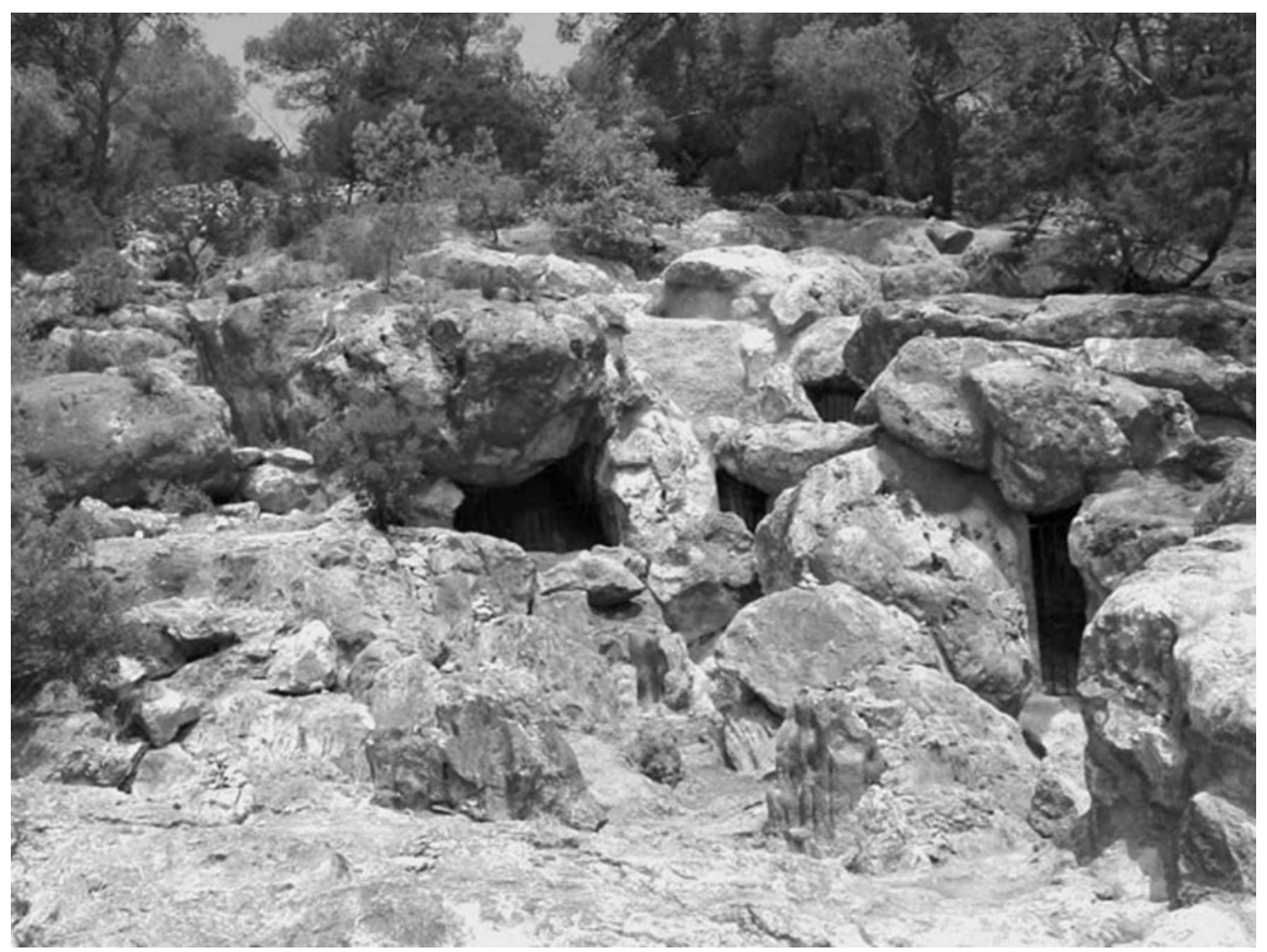

Figure 1. The Es Culleram cave (photograph by the author). 


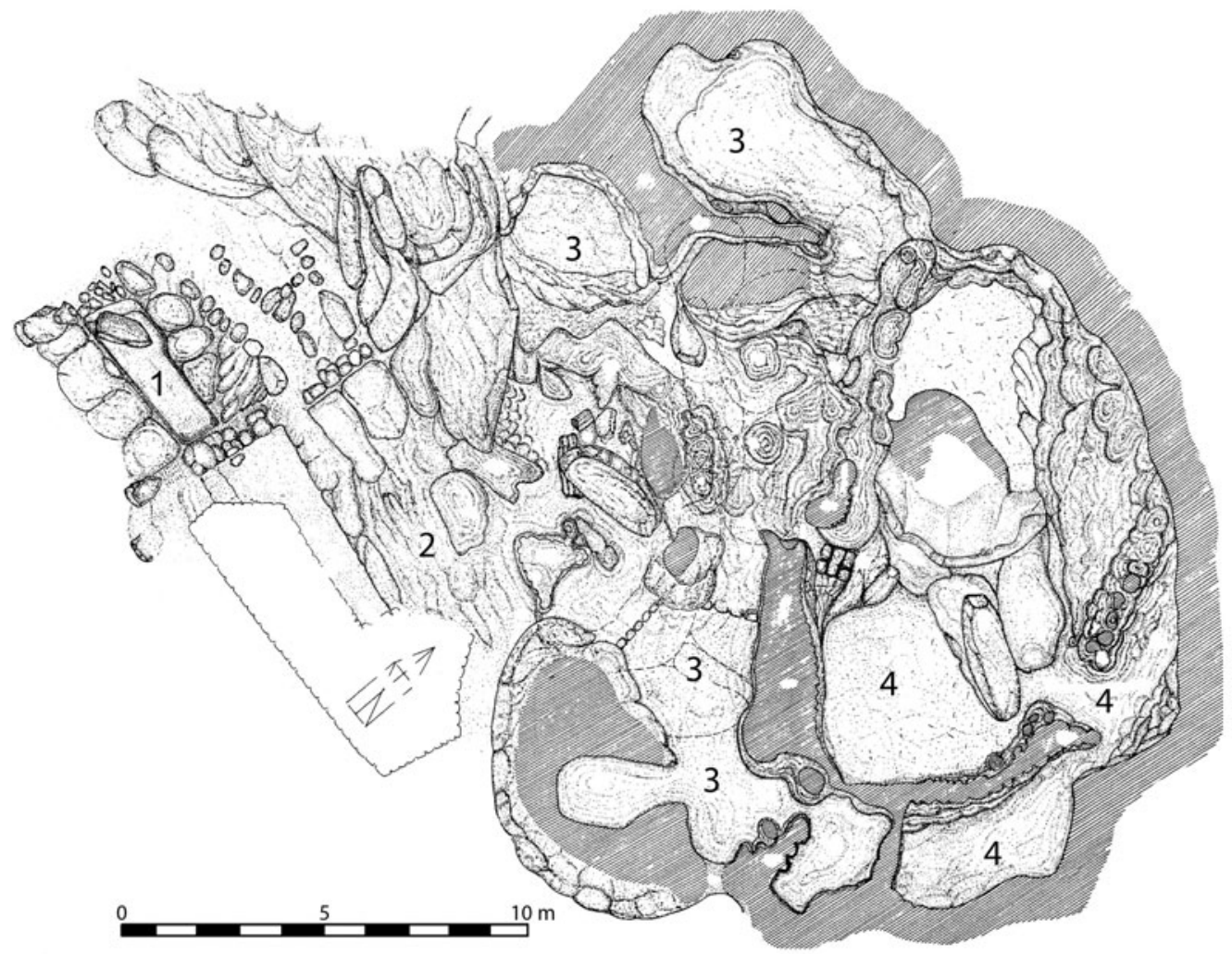

Figure 2. Layout of the Es Culleram cave (adapted from Ramón 1985).

rock, which collects rainwater. The cave has a total surface area of $200 \mathrm{sq} \mathrm{m}$. It was used from the 4th to the 2 nd century $\mathrm{BC}$ with a peak of activity during the 3rd century (Ramón 1985: 233-35; Gómez Bellard and Vidal González 2000: 112).

The cave was excavated in 1907, 1909, 1965, 1968 and 1982. A large number of finds were recovered from the cave when it was first explored in 1907 and 1908, including 788 terracotta figurines. Unfortunately, no information whatsoever was recorded concerning their contexts. Among the five iconographic models that have been identified, I will treat the 'winged figurines', 'plain figurines' and the 'incense burners' (not the 'enthroned figurines' and 'various types'). The winged figurines, which are unique to the Es Culleram cave, depict females usually seated on a throne wearing a kalathos (headdress). The wings, the herald's wand (caduceus) and the solar disc or lotus flowers that the figure wears identify her as representing the Carthaginian goddess Tanit. The plain figurines are characterized by obvious iconographic references to Demeter such as a kalathos, a veil, torches, piglets and babies. The 17 incense burners (thymiateria) are in the shape of a female head habitually associated with the cult of Demeter and Persephone. It is unclear, however, whether any of these objects were actually used to burn incense or other spices; they might also represent votive offerings (Aubet 1982).

Other finds include coins from Ibiza, two stones that may have been baetyls to judge from their conic section, two gold medallions and two Punic inscriptions written on a bronze support dedicated, respectively, to the goddess Tanit and the god Resheph-Melqart. Significant amounts 
of pottery were also found, in particular cooking, eating and drinking vessels as well as some amphorae. Many of these vases are smaller than usual and can be considered as miniatures (Ramón 1985). The presence of large quantities of animal bones, almost exclusively sheep and goats, shows that eating was also a regular activity in or outside the cave and suggests that sacrificial meals were a significant feature of the rituals performed at Es Culleram. Careful analysis of the faunal remains has also shown that most of the animal skulls were burnt and that the animals had been slaughtered in the cave itself (Aubet 1982; Ramón 1985; Morales Pérez 2003: 112).

For its part, Gorham's cave is a cave-sanctuary situated at the base of the Rock of Gibraltar on its east side, the steeper side that faces the Mediterranean (Figure 3). Its location is highly significant-at the meeting-point between the Mediterranean and the Atlantic at the most dangerous point on the Atlantic route. The cave consists of a long corridor (50 $\mathrm{m}$ in length); the entrance is $7 \mathrm{~m}$ wide, but the cave grows narrower towards the rear. The site was discovered in 1907 and excavated intermittently between $1945-54$ by Waechter who dug the hall of the cave. Modern digging campaigns took place from 1997 to 2000, concentrating on the back of the cave. Although the cave was used during the Palaeolithic, Phoenician and Punic sailors visited it from the 8th to the end of the 3rd century вс (Waechter 1951; 1953; Gutiérrez López et al. 2001: 15).

The finds vary widely and include Tartessian pottery (Late Bronze-early Iron Age pottery handmade by the local inhabitants of southwestern Iberia), Phoenician imports from the east, and scarabs that are among the oldest materials from the 8th-7th centuries BC (Belén and Perez 2000: 532; Gutiérrez López et al. 2001). Some of the numerous scarabs bear hieroglyphics, whereas others show depictions of the god Bes, or men riding horses or fighting against lions; they are dated between the 7 th- 5 th centuries $\mathrm{BC}$ and have been interpreted as apotropaic objects (Culican 1972; Posadas 1988; López de la Orden 1995). The cave also contained fragments of human clay figurines: part of a human-like face with a hat, two other pieces of human-like faces interpreted as funerary masks and a fragment of a small statue of the god Bes. There are also rings, beads, fibulae, hooks and amulets of glass paste (Culican 1972). As
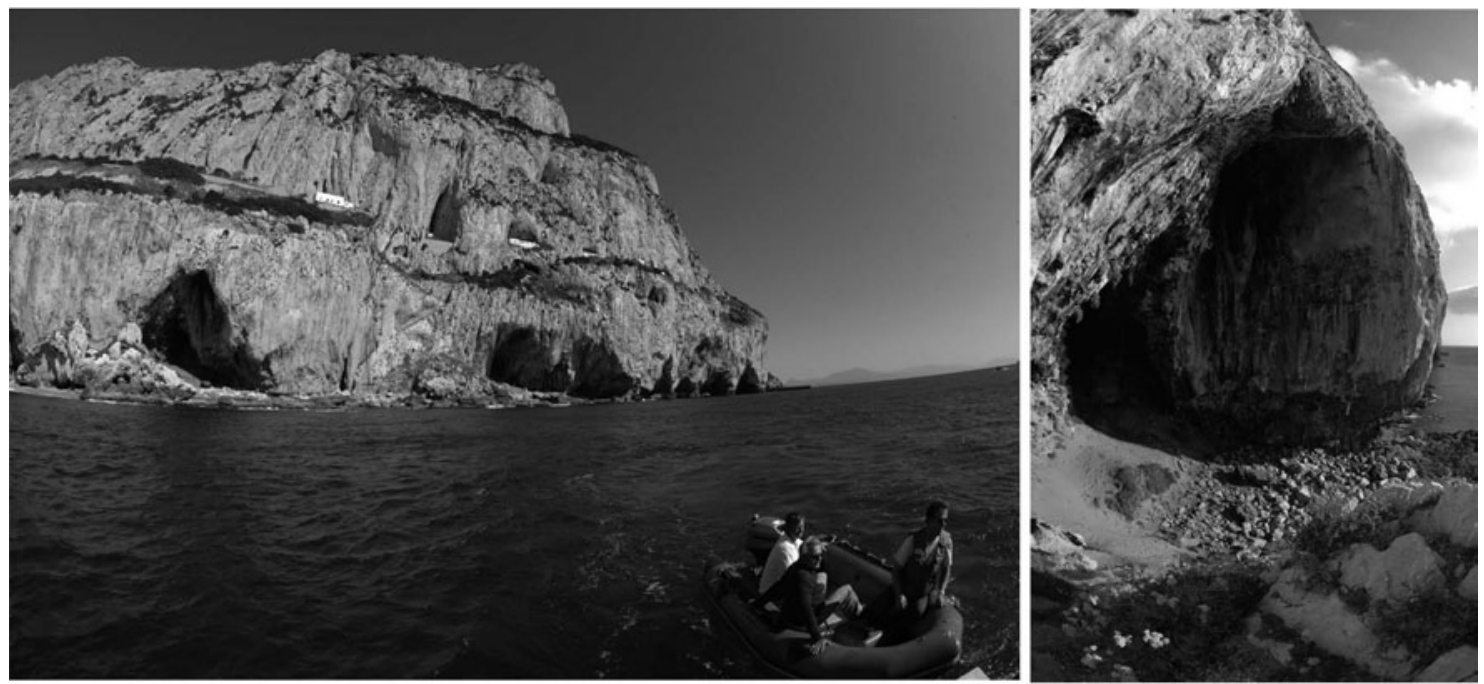

Figure 3. Left: the Rock of Gibraltar from the east. Gorham's cave is the first cave from left. Right: entrance to Gorham's cave (courtesy of the Gibraltar Museum). 


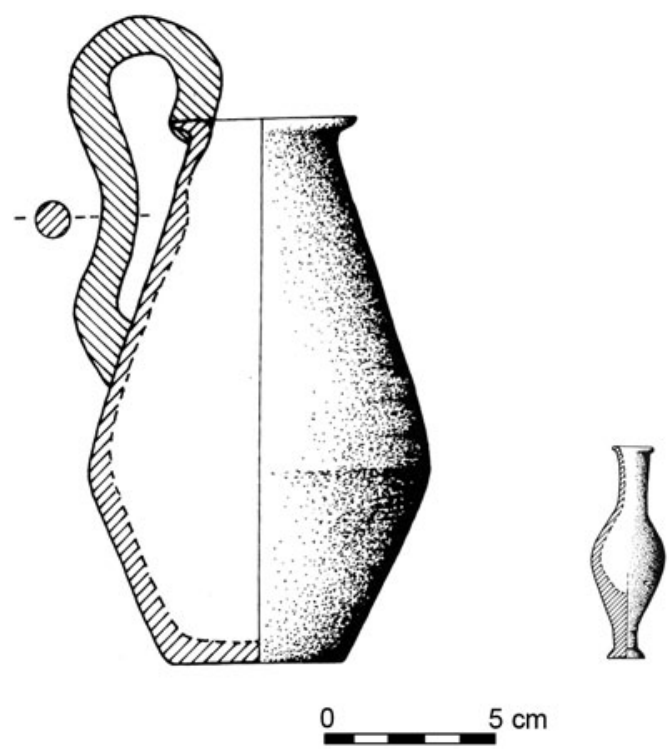

Figure 4. Bottle and perfume bottle from Gorham's cave (adapted from Belén and Pérez 2000).

to the pottery, open forms are the commonest: plates, bowls and bowls used as incense-burners, executed in Attic black gloss, Kuass-type gloss (imitations of Attic black gloss pottery produced in north Morocco and southwestern Cádiz) and coarse ware productions. The closed forms - the minority-included amphoriskoi and aryballoi, small bottles to store oils or perfumes (Figure 4). Among the handmade pottery are bowls, casseroles, pots and à chardon (thistle-shaped) vases (Belén and Pérez 2000: 533; Gutiérrez et al. 2001: 16). The large amount of materials from the 5th-3rd centuries BC suggests that the cave reached its peak of activity during this period.

\section{Journeying to the Shrines: Movement as Per- formance}

In general terms, pilgrimages are defined as circular (back and forth) journeys in search of a space or mental state that embodies an ideal. In this view, movement is the central element that defines these journeys (Coleman 2002: 36163; Morinis 1992: 4). In this section I aim to explain how people participated actively in the creation of the landscape and the seascape when they travelled to the caves.

In this paper, the use of the term 'performance' stresses the transformative features of the concept (Inomata and Coben 2006: 19; Mitchell 2006: 384-85). But what transformations were carried out by the people travelling to the cave-shrines? In my view, the religious connotations of visiting the shrines make the journeys ritualized. But in order to do this, it is first necessary to transform the space where people move into familiar landscapes and seascapes. In this section I concentrate on two types of transformations: first, the creation of landscape and seascape by travelling and, second, the ritualization of the two elements once they have been incorporated into daily practices.

The Creation of Landscapes and Seascapes: the Local Contexts

It has been stressed that navigation was essential for communication between people from different settlements located relatively close to each other in the Phoenician and Punic worlds. On the island of Ibiza it would have been easier to travel by sea along the coast than overland (Figure 5); the Sant Vicent valley, highly isolated until the beginning of the twentieth century, is a case in point (Costa 2007: 8; Gómez Bellard et al. 2005: 30). Moreover, the south Iberian coastline, especially from Algeciras to Almería, had a great many Phoenician settlements that would have communicated with each other by sea rather than by land (Delgado 2008: 372). The same was true for the settlements on the shores of the Straits of Gibraltar (Aranegui and Hassini 2010; Bernal and Sáez 2008). In such contexts, the visits to these two caves as shrines should be read in connection with the local inhabitants creating a familiar landscape and seascape.

According to surveys carried out in two rural areas (Can Francesc and Can Vicent Gat) in the Sant Vicent valley in northern Ibiza, the area began to be settled at the end of the 5th century, precisely the moment when Es Culleram 

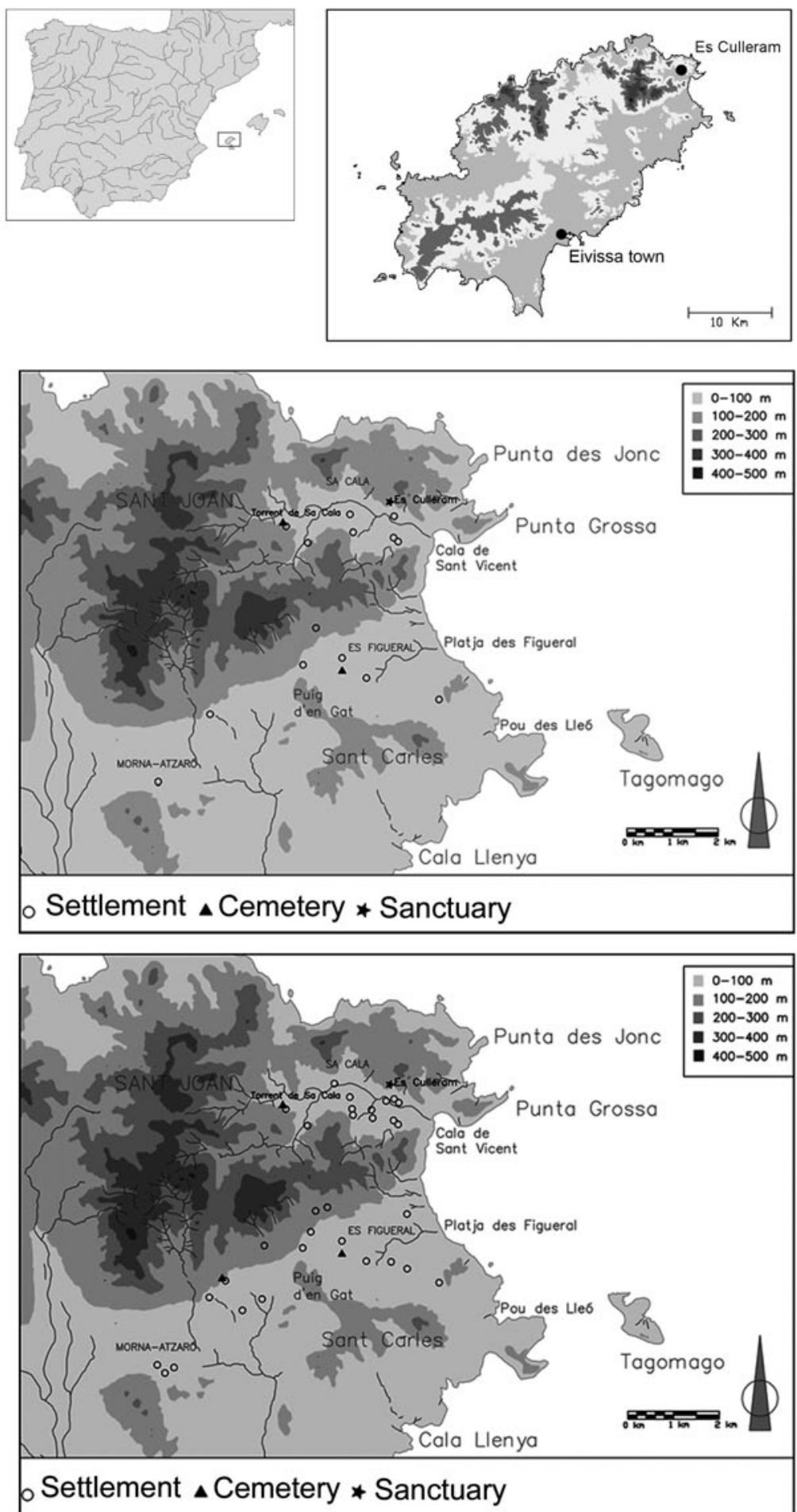

Figure 5. Map of Ibiza showing Es Culleram and the rural settlements of the Sant Vicent valley; above: fifth-century settlements; below: third- to second-century settlements (adapted from Gómez Bellard et al. 2005).

\section{eevinoxonline}


appeared as a shrine. During the 3rd-2nd centuries $\mathrm{BC}$, when activity in the cave was at its peak, the number of rural settlements increased from eight to 14 (Gómez Bellard et al. 2005; Gómez Bellard 2008: 63). These rural settlements were involved in the exploitation of the valley's agricultural resources, which covered some $4 \mathrm{sq} \mathrm{km}$. Farmsteads were located along the central stream of the valley and were close to each other, no more than $500 \mathrm{~m}$ apart, suggesting landholdings of no more than 10 to $12 \mathrm{ha}$. The farms exploited the valley itself, because the valley slopes are steep and they might have taken advantage of the Sant Vicent stream to irrigate the crops (Gómez Bellard 2008: 70-71).

This scenario suggests that Es Culleram was mainly visited and used by local people, especially if we bear in mind that the cave is not easy to see either from the sea or from the cove. The most salient evidence of the local connection comes from the winged terracotta figurines representing Tanit; to date, these have been identified exclusively in Es Culleram. This suggests that they may have been produced by a workshop located in the area of the sanctuary, although intensive surveys carried out in the valley have not provided any convincing evidence (Costa 2007: 24).

The creation of landscape is clearly attested in Es Culleram. The rural settlements were spread all over the valley; although the oldest ones were located close to the beach, by the third century onwards the newer farms were located on higher ground in order to exploit the soils close to the stream. The highest settlement, Can Lluquí, was $3.5 \mathrm{~km}$ from the sea and 104 m above sea level (Gómez Bellard et al. 2005: 38). Therefore, to approach Es Culleram visitors would have had to climb the hill; this would have taken around $30-40 \mathrm{~min}$, as the distance is $1.5 \mathrm{~km}$ from the cove (Figure 6). Walking is as important as sailing for transforming spaces in everyday landscapes and according to the data from the rural settlements of the area, we might argue that walking along the mountain was a common activity. People would create landscapes through walking; in fact, they literally left footprints in the landscape (Ingold 2004: 329).

The other area of study, the Straits of Gibraltar and southern Iberia in general, was a densely inhabited area in antiquity. Along the Bay of Gibraltar, where Gorham's cave is located, other Phoenician and Punic settlements have been identified (Cerro del Prado and Carteia respectively: Gutiérrez López et al. 2001: 28). Because Cerro del Prado, Carteia and Gorham present similar materials, it has been proposed that the inhabitants of these settlements visited the cave.

The Bay of Gibraltar is considered a shelter because of its calm sea. Once outside it, ships find themselves in the most dangerous area between the Atlantic and the Mediterranean and have to contend with particularly strong currents and winds. Thus, the presence of Phoenician and Punic settlements in the bay comes as no surprise. Indeed, Cerro del Prado was a Phoenician settlement of about two ha on the mouth of the Guadarranque River, situated some $25 \mathrm{~m}$ above the sea with an excellent view of the bay. In existence from the 7th-4th centuries BC (Roldán Gómez et al. 2006: 81-89), the settlement's function was mainly maritime as the mouth of the river was larger than it is today and offered an excellent site for a jetty. A great many objects related to both saltwater and freshwater fishing have been recovered: hooks, weights, nets and amphorae that may well have stored fish-based products. Cerro del Prado thus served as an anchorage settlement that may have controlled the traffic through the Straits of Gibraltar; it was also the last secure outpost in the network of Phoenician coastal settlements before the Atlantic ocean (Roldán Gómez et al. 2006: 531). The distance across the sea between Cerro del Prado and Gorham's cave is about $10 \mathrm{~km}$. Assuming a navigation speed of five knots, the trip would have taken an hour in fair weather. As noted above, Gorham's cave is only reachable from the sea, as it is located at the bottom of a steep cliff. 

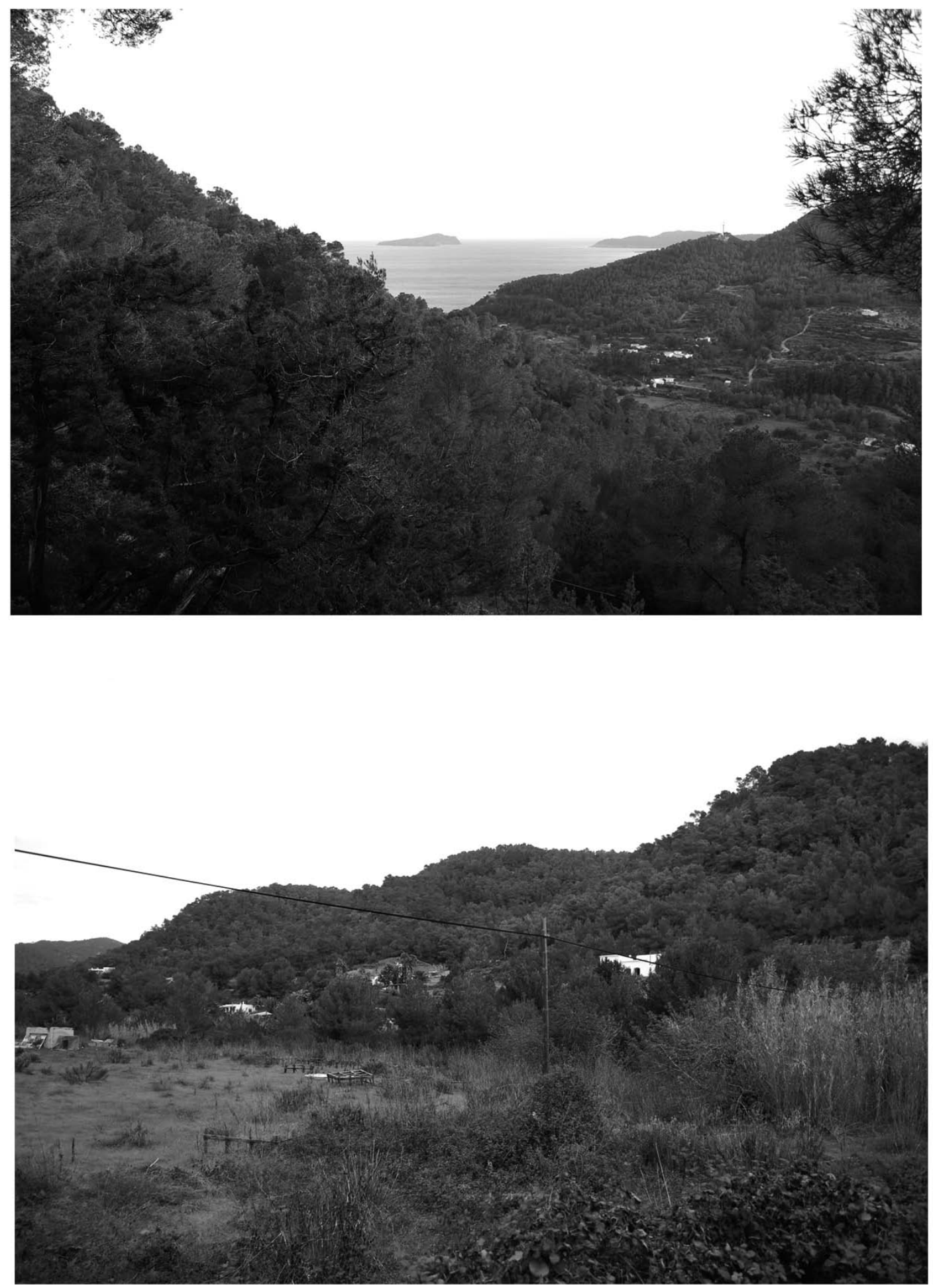

Figure 6. Top: view from Es Culleram. Bottom: view over the Sant Vicent valley (photograph by the author).

(C) The Fund for Mediterranean Archaeology/Equinox Publishing Ltd., 2011

\section{eevinoxonline}


Gorham's cave also had connections with Carteia, a Punic city on a hill on the other side of the mouth of the Guadarranque River. Carteia appears to have been created as an expansion of Cerro del Prado in the mid-4th century вс. Because of more favourable geographical conditions and its larger size, Carteia eclipsed Cerro del Prado by the end of the 4th century BC and the latter was gradually abandoned. Essentially, Carteia was a walled city devoted to fishing and salt production. The types of amphorae found reinforce the role of fishing and salting activities in Carteia as well as the local traffic of people moving through the Bay of Gibraltar: $80 \%$ of the amphorae are from the Atlantic area of the Straits, whereas only $10 \%$ are from the area of Málaga and Granada (the eastern Mediterranean coast of Iberia). Small numbers of amphorae from Carthage or Ibiza have also been identified (Roldán Gómez et al. 2006: 364-66, 532).

Another settlement close to Gorham's cave is Montilla, located at the mouth of the Guadiaro River on a small hill. Montilla was an anchorage, an outpost of the indigenous inhabitants that had connections with Alcorrín, an indigenous fortified settlement $6 \mathrm{~km}$ farther inland (Delgado 2008: 448). Surveys have recorded an early period in which only handmade pottery is preserved, and a second phase with handmade pottery and Phoenician pieces: red slip plates, amphorae, bowls and pithoi (storage vases) (Schubart 1987). The site was inhabited between the 8 th and 7 th centuries BC.

The connection between Montilla and Gorham's cave can be inferred by the similarity of the handmade pottery in the two sites. The distance between them is $25 \mathrm{~km}$ and the sea journey must have taken around three hours. This is particularly significant because it clearly reinforces the local use of Gorham's cave, even before the arrival of the Phoenicians in the Bay of Gibraltar. Indeed, maritime traffic was already quite intensive between the Mediterranean and the Atlantic in the Bronze Age (Ruiz-Gálvez
2005: 325). The important role of navigation in that area is attested in the boat paintings of La Laja Alta (Jimena de la Frontera, Cádiz: Barroso 1980: 23), a cave located on a gorge $400 \mathrm{~m}$ above sea level. The cave provided an excellent view of the Janda lagoon, a bay connected to the Mediterranean by a number of channels. There are seven representations of boats at La Laja Alta, some defined as junks (thus reflecting local navigation practices), others with an oriental appearance (Ruiz-Gálvez 2005: 317-18; Guerrero Ayuso 2008: 91-97). This evidence stresses that the Bay of Gibraltar and its hinterland was intensively visited and inhabited not only after the arrival of the Phoenicians and Punic people but also during the preceding Bronze Age, when Gorham's cave would already have been used by the area's indigenous inhabitants.

If we consider the Straits of Gibraltar as a broader local context for the cave, the material culture also suggests connections with other settlements: most of the pottery types from Gorham's cave (handmade pottery, coarse ware, grey and painted wheelmade pottery) are also found in other settlements to the south and north of the Straits of Gibraltar, like Ceuta (Villada et al. 2007), Lixus (Aranegui 2005) and Castillo de Doña Blanca (Figure 7). In spite of the intense connections that these suggests, the settlements of the Cádiz area were likely to have been more closely related to Gorham's cave, when the use of the cave was at its peak (5th-3rd centuries $\mathrm{BC}$ ), coinciding with the establishment of Cádiz as an important centre of fish-based products (Belén and Pérez 2000: 534).

These data demonstrate that visits to the caves were made in a context of well-known seascapes and landscapes. Thus the local population may well have used the caves as shrines in order to mark the landscape and seascape, and thus to appropriate them (Taçon 1994). Travelling to the shrines would have been a significant action in itself because it would make them more familiar spaces and would help to establish people's social identity (Coleman and Eade 2004: 

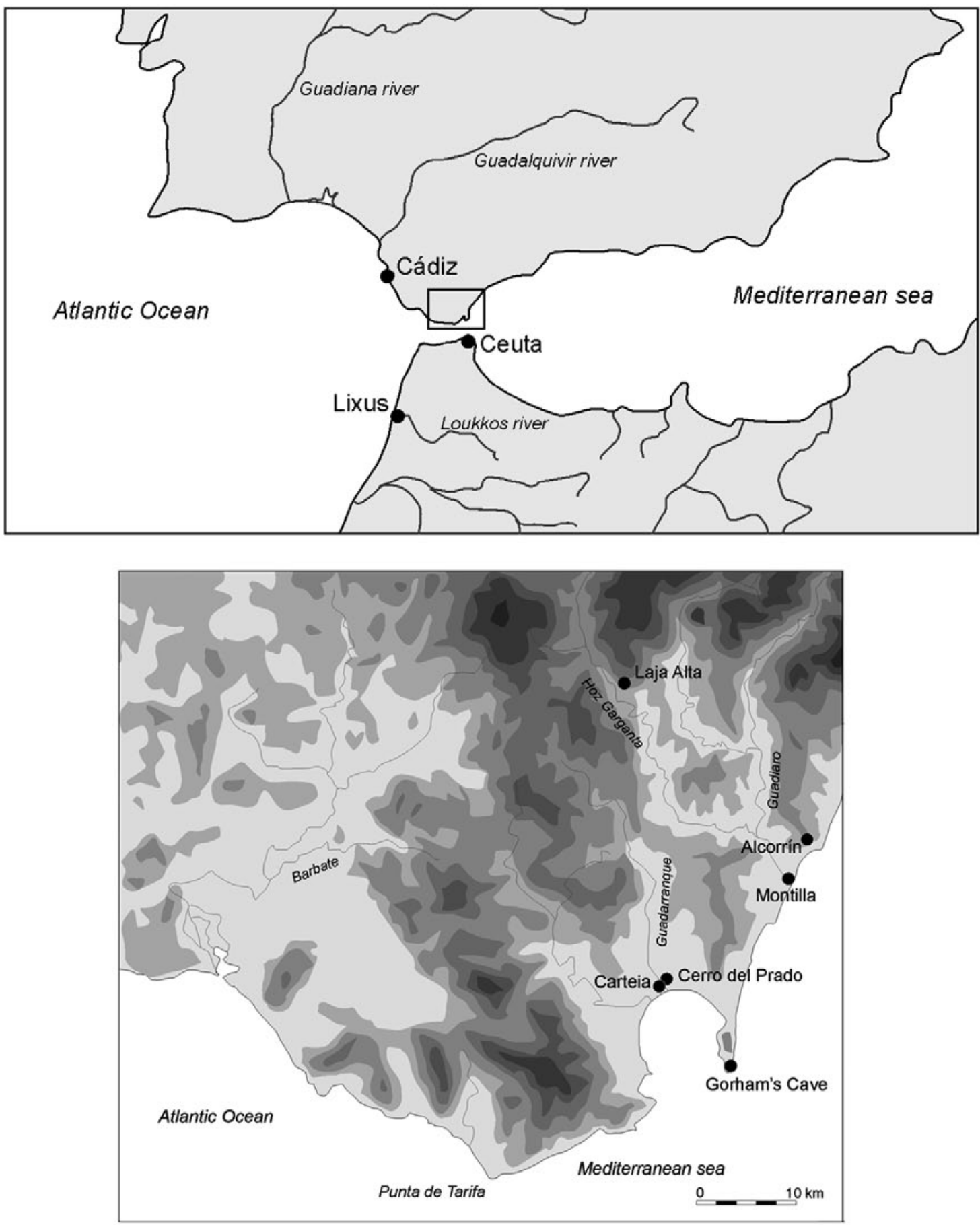

Figure 7. Map: Straits of Gibraltar.

\section{eevinoxonline}


16). Through their travels, therefore, the people created both the landscape and the seascape (Cummings and Johnston 2007: 2).

\section{The Ritualization of Landscapes and Seascapes}

Travelling to the caves to perform rituals makes it possible not only to socialize landscapes and seascapes but also to ritualize them and the activities performed within them. This is borne out by the presence of certain materials related to maritime aspects of daily life: several fragments of fishplates, especially painted ones, have been found in Gorham (Gutierrez López et al. 2001: 20); hooks are regarded as votive offerings and fish and mollusc remains have been taken as proof for the consumption of foodstuffs (Figure 8). Fish and molluscs were staples of the inhabitants' diet and their presence in the caves indicates the ritualization not only of consumption but also of the materials themselves, as they become votiveofferings (López-Bertran 2007: 115).

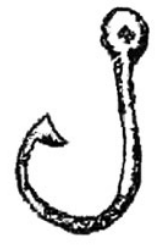

1
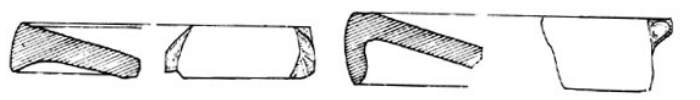

0 $3 \mathrm{~cm}$

Figure 8. 8.1: Hook from Gorham's cave; 8.2: fish-plates from Es Culleram (adapted from Culican 1972; Ramón 1985).

Since the seascape is a familiar area, it is natural that people endow the sea with cosmological value. The sea is seen as a living entity with its own changing identity: it provides food and the possibility of mobility, but also brings natural disasters like flooding or shipwrecks. Indeed, many of the representations of Phoenician and Punic seascapes in the Mediterranean contain representations of fantastic and hybrid beings such as fish-men or dragon-fish (López-Bertran et al. 2008: 348-49). These creatures are considered maritime spirits and seascapes become 'spiritscapes' in which they have extraordinary powers; according to McNiven (2003: 330), seascapes are full of such characters that can be engaged through ritual in order to mediate human spiritual relationships with the sea.

Certain materials from Gorham's cave emphasize the idea that people performed rituals in order to control or mediate the sea, its symbolic features and, perhaps, the fantastic beings thought to inhabit it. This ritual engagement can be interpreted through the iconography of the images on 11 scarabs found at the site, five of which are relevant to the present discussion. One represents what looks like a bird with open wings, or even a siren; another depicts a rider, a theme interpreted as the representation of the god Yam, a seafaring divinity (López de la Orden 1995: 127). The other three scarabs represent the god Bes, a god that has an apotropaic and prophylactic function, and has been associated with what is known as 'maritime religion'-more specifically with the Pataikoi, a kind of maritime spirit often depicted on ships' figureheads, one that was iconographically very similar to Bes (Fantar 1977; Brody 1998: 38; Romero Recio 2000: 153-55; López de la Orden 1995: 121).

The symbolic and ritual aspects of travelling also materialized in the ships themselves. Thanks to a number of funerary stelae from Carthage, we know that boats were decorated with representations of goddesses, gods or astral symbols (Hours-Médian 1951). Apotropaic eyes were also depicted on the prows of most Punic ships and have been explained in magical and symbolic terms: placed at the very front of the boat, they have an emblematic value in the area that guides navigation and wards off ill luck (Brody 1998: 63; Romero Recio 2000: 27). Similarly, some Classical authors record that ships were named after divinities (López-Bertran et al. 2008: 34850). Equally interesting is a ceramic boat vessel 
in sanctuary IV of el Carambolo (Camas, Seville) that represents a hippos, i.e. a Phoenician commercial seagoing ship (Escacena et al. 2007).

The use of caves as pilgrimage shrines and the attribution of a cosmological meaning to the sea are significant ways of constructing and ritualizing seascapes. Ritualizing the sea and sea journeys helps to emphasize its liminal character or, more specifically, that of the seashore. As an area of contact between land and water, the sea had a symbolic role in the life of society. Divinities and fantastic animals inhabit liminal worlds, and water, in general, is a fascinating and powerful element (Meskell and Joyce 2003: 80). Furthermore, the symbolic role of water is attested not only by the sea but also by water in the caves. Because of their geomorphologic features, both caves discussed here contain water, which we might label 'abnormal water' because it appears in extraordinary forms like stalactites, stalagmites and waterfalls (Whitehouse 1992; 2007: 97).

Es Culleram is connected with both the landscape and the seascape. On the one hand, fishplates together with seven weights and sinkers from fishing nets have been identified as votives that evidently relate to maritime activities. On the other hand, the materials related to Demeter (incense-burners, figurines holding babies, piglets) are associated with the rural context of the cave and the intensive use of the landscape for agriculture. But the 'winged-figurines' are surely the most salient feature related to the ritualization of both the seascape and the landscape.

The wings of the terracottas are decorated with palms, lotus flowers and lunar crescents above a disc. The crescent has been associated with the astral features of Tanit and it has been argued that the symbol may be a representation of Venus above the moon. There is also a connection with the sea and navigation, as Venus is considered to be the star that guides seafarers and illuminates their path (Medas 1998). So people may well have used the winged figurines to placate the sea and its fantastic beings.
Tanit, however, is also linked to agriculture and nature, and the lunar crescent has been used to stress her agricultural connotations. Tanit was associated with Ba'al Hammon, the god of agriculture, and she ruled meteorology, the cycles of nature and fertility in general. Rather than identifying the role of the figurines, I want to emphasize the connections of these materials with daily activities like sailing or agriculture, and with landscapes or seascapes, I also want to show the practical dimension of the materials (sensu Bourdieu 1977).

In Es Culleram, there are traces of the ritualization of both navigation and walking. People would have walked through familiar landscapes, as the valley of Sant Vicent was densely occupied by rural settlements exploiting the land and the Sant Vicent stream. But they did this with a special purpose in mind: to visit the shrine in order to perform rituals. As ethnographic evidence shows, especially in the Santiago de Compostela pilgrimage (Candy 2009: 132-34), the act of walking allows pilgrims to link physical experiences with spiritual ones: people focus on the practice of walking itself and its rhythm and this creates a ritual spiritual atmosphere (Slavin 2003: 7).

The journeys to the shrines can be considered as ritualized acts. People travel to shrines for extraordinary purposes but, at the same time, they use not just an everyday landscape or seascape but everyday forms of movement as well: navigation as well as walking (López-Bertran 2007: 133). People go to shrines to perform rituals and to do so they must move; as I suggested above, people must move through landscapes and seascapes in order to become familiar with them. The process of making seascapes and landscapes simultaneously familiar and ritualized is a circular one: as the sea and the land are experienced as daily areas of living, they take on symbolic and cosmological meanings. The way to deal with these elements is to ritualize movement not just through the seascape but also through the landscape; this applies in par- 
ticular to the caves as transitional areas between seascape and landscape. In visiting the shrines, people used a common way of moving through a daily landscape but the ritual dimension makes it nevertheless a different experience. In other words, ritualization is generated not only by the use of caves as shrines, because they connect daily seascapes and landscapes, but also by the use of everyday items alongside specialized ritual objects such as representations of divinities or jewellery. This is a clear example of how ritualization involves a question of scale and grade, and how rituals are entangled with activities and objects of daily life (Bell 1992).

\section{Embodying Mobility}

\section{Movement Inside the Caves}

Pilgrimages involve movements of people and people move with their bodies. Thus pilgrimages create bodily experiences not only during the journey but also once the visitors have reached the shrines. Movements performed inside and outside the caves have a corporeal and sensual dimension that, in many cases, helped the visitors to experience a metaphorical or spiritual journey. In this section, I therefore interpret movements in terms of embodied actions and of how these bodily movements help to achieve metaphorical journeys (Coleman and Eade 2004: 16-17). The embodiment approach makes it necessary to consider both a phenomenological perspective (Tilley 2004) and the archaeology of the senses (Skeates 2010).

When approaching the caves, the experiences and perceptions of the landscape and the seascape would have been different at our two sites, if only because Es Culleram, for example, was approached from below. As the cave is not easily visible either from the cove or from the valley, I argue that walking can be perceived as a discovery through which people encounter the cave. The same can be said of the visitors who arrive from the sea by boat: from the cove of Sant Vicent the cave is completely hidden.
What we might thus call the 'sense-scape' of the pilgrimage would have been accompanied not only by the sounds of breathing and footsteps, but also by the sounds of nature: the stream, the sea, the wind, or even insects.

The approach to Gorham's cave is quite different. The only way to reach the cave is by boat, and the journey would have taken between one and three hours, depending on the distance from the settlements in the Bay of Gibraltar. Seen from the sea, the cave would be a far less significant landmark than the Rock of Gibraltar, which is after all $5 \mathrm{~km}$ long, $1 \mathrm{~km}$ wide and $424 \mathrm{~m}$ high) and which would have been a key point of reference for orientation and for creating cognitive maps. It has been argued that people would have performed rituals on the boats approaching the Rock rather than inside Gorham's cave itself (Vella 1998: 374-90). I agree with connecting the sacred nature of the cave to the Rock of Gibraltar and the practice of way-finding in antiquity (see above, pp. 87-88), but I also think that ritual activities took place in Gorham's cave itself, as suggested by the presence of votive offerings (jewels and rings, fibulae in gold, silver, iron and bronze) together with a terracotta figurine of the god Bes and the consumption and production of foodstuffs. I would indeed argue that the important role of the Rock of Gibraltar in creating the landscape and seascape of the bay led to its sacralization. In this sense, Gorham's cave may be considered as a kind of metonym of the Rock where rituals were performed in connection with the total landscape and seascape, while the sea journey towards it may have been the first in a series of ritual activities. Approaching the Rock and the cave must have been an impressive experience, accompanied by the sound of the sea; once the boats docked on the small beach, people would have had the impression of penetrating deep into the Rock.

Es Culleram and Gorham's cave also differ in terms of the movements carried out during the performances. On reaching Es Culleram, visitors would have bathed or drunk water at the 


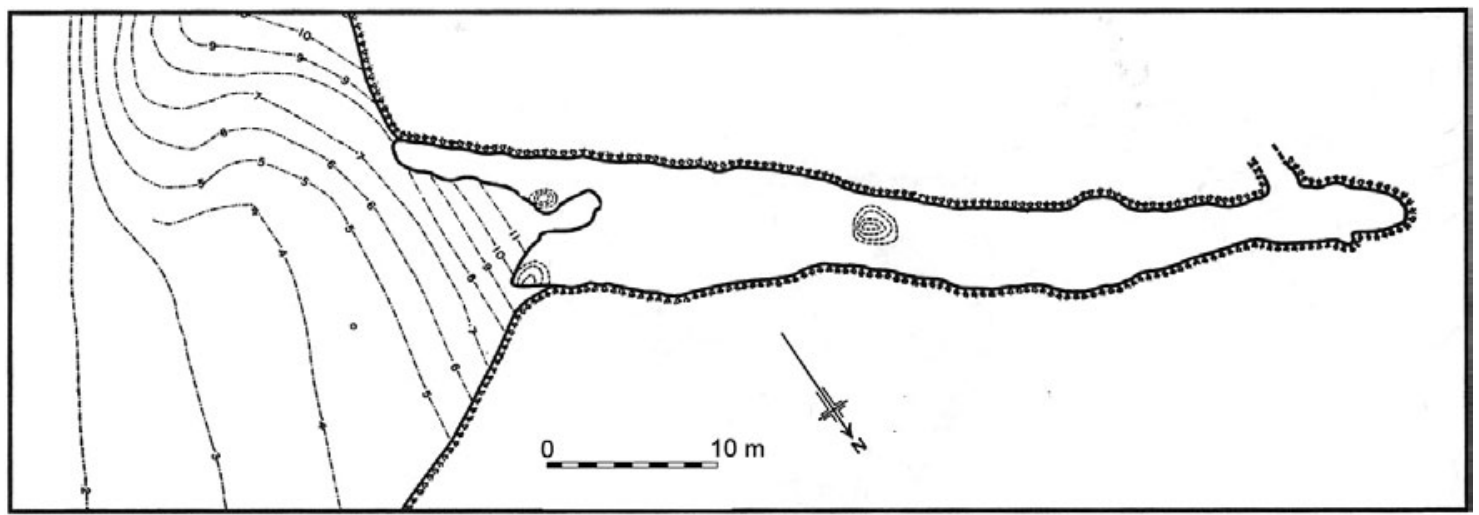

Figure 9. Layout of Gorham's cave (adapted from Waechter 1951).

cistern just outside the cave as a purifying act. Pilgrims would have begun a journey that was both physical and symbolic, from the external to the internal world. First they would have stood at the entrance to the cave, a transitional or liminal area with natural light. Then they would have entered the cave, and found two areas with different bodily effects: the small rooms between 1.5-2 $\mathrm{m}$ high, where they would have crouched down in poor light and with little air, before entering the holy of holies, a large area $5 \mathrm{~m}$ in height. Unfortunately, we cannot determine the ritual practices that took place in each area of the cave because the archaeological reports do not mention how the finds were distributed. It has been suggested, for instance, that the inner room might have been used only as a deposit (Costa 2007: 11), but the distribution of the figurines suggests otherwise, as fragments of the same figurines have been found throughout the cave, as if they had been broken intentionally (Aubet 1982: 45).

In Gorham's cave, on the other hand, space would have been perceived and felt quite differently. It certainly shares with Es Culleram the symbolic value of travelling to a hidden and unknown world, but there is no water structure at the entrance. Entering the cave would have been difficult because visitors had to climb a steep slope some $17 \mathrm{~m}$ high (Gutiérrez López et al. 2001: 18). Once inside, walking would have become much more difficult as the visitors progressed from the wide entrance to the narrow rear end; as they moved inside the cave light would have become dimmer and dimmer and people may well have stumbled over the many stalagmites (Figure 9). Different rituals would have taken place in the two areas of the caves. At the sun-lit entrance cooking and eating vessels as well as fauna and bonfire remains point to the consumption of food, while the rear part in total darkness was full of votive offerings.

In both cases, however, movement into the cave-shrines was essential for participating in ritual performances. The physical movement towards the rear of the cave embodied the symbolic movement of the attempt to engage with the divinities. Although the routes to the rear of the two caves differ because of their specific features, the sites would have shared similar sense-scapes that were defined by dampness, abnormal coolness, difficulty in performing body movements, restrictions of light and air and reverberating sounds (Tilley 2004: 131-32; Skeates 2007: 94).

\section{Movements as Metaphors: The Otherworldly Journeys}

The use of material culture suggests body movements and sensory experiences that are essential to explaining the visitors' metaphorical journeys. I would therefore like to emphasize not just 
the materiality of the ritual performances but also that the 'symbolic' dimensions are equally embedded, embodied and achieved with and through bodies and objects.

Both caves evidently lacked light but the archaeological record shows that the visitors responded to this situation in different ways. In Es Culleram, surprisingly few oil-lamps, incense burners and oil and perfume bottles were found, and none of the thymiateria (incense-burners) showed traces of burning. In Gorham's cave, by contrast, the numerous oil-lamps, amphoriskoi, aryballoi, bowl-lamps and double-plate incense burners offer many indications of burning.

This evidence suggests the importance of sight, both physical and symbolic. Lighting must have
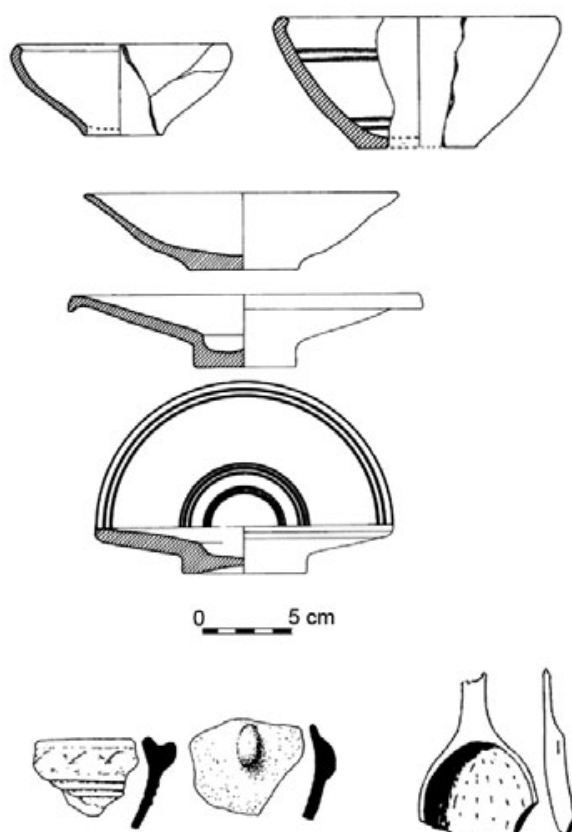

A

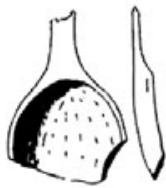

been essential in Gorham's cave, especially given its narrow passages. At Es Culleram, the question is whether the illumination of the cave was unimportant or whether the visitors took their oil-lamps away with them (because they were not considered votive offerings), or used torches that did not leave traces (López-Bertran 2007: 14647). In any case, the key point is the symbolic aspect: even if people illuminated the cave, the amount of light would still have been limited and it would have been diminished further by the smoke of burning oils or perfumes. The reduced sense of sight would have been compensated by an enrichment of the other senses, so that people would have seen and experienced blurred faces, gestures and activities (Skeates 2007: 93)
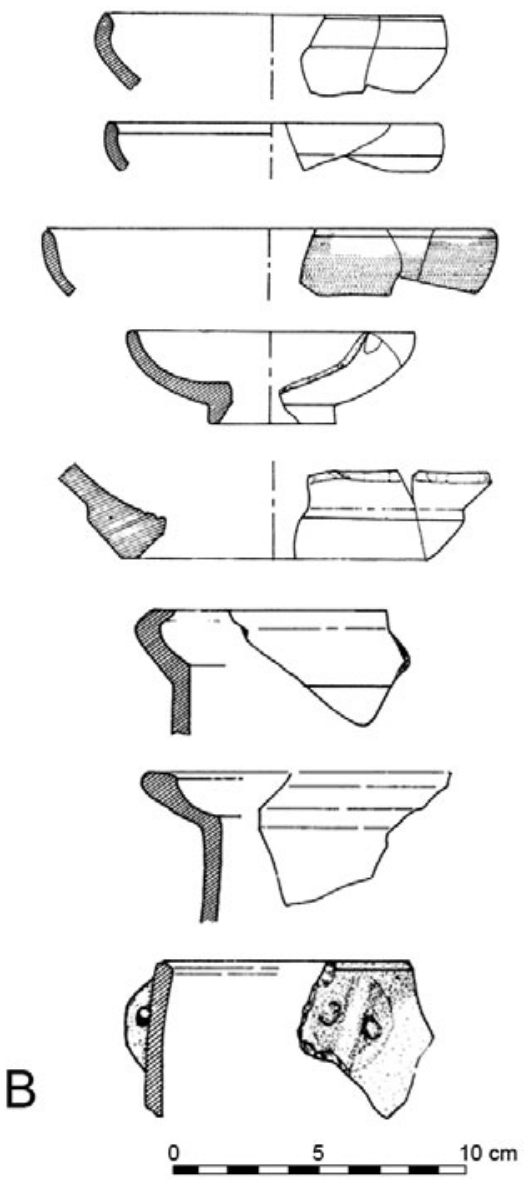

Figure 10. Cooking and table pottery from Gorham’s cave (a) and Es Culleram (b) (adapted from Ramón 1985; Belén and Pérez 2000; Culican 1972). 
The importance of fire and burning is attested in both caves in relation to the slaughtering of animals and cooking practices. Pots, mortars and pans have been found in both shrines (Figure 10), and in Es Culleram the faunal remains show how the animals (young sheep and goats) were burned, especially the skulls in the cave itself (Morales Pérez 2003). The ritual practice of burning oils, animals and cooking would undoubtedly have made the atmosphere thick with smoke.

Poor visibility, thick smoke and hot fire would have created in turn an appropriate ritual atmosphere to embark on a symbolic journey in order to commune with divinities, ancestors or fantastic beings. This may be related to the exploitation of smell as an important sense to make people move metaphorically. Unfortunately, we do not know what sort of materials was burned, although it was probably oils, perfumes, incense and animals. We may also assume that the inhalation of some of these substances could have caused altered states of consciousness, as recorded in examples elsewhere (Sherratt 1991: 51-52; Guerra 2006).

Achieving an altered state of consciousness may be related to the consumption of food and beverages. We have some material evidence to support this argument in the form of mortars and the miniaturization of some ceramic vessels. In Gorham's cave and Es Culleram, the mortars and bowl-mortars that have been found may have been used in consuming some alcoholic beverages, especially wine. Some classical texts report that people used to add psychotropic substances to alcoholic beverages (Guerra 2006: 132), and some scholars have interpreted the combination of mortars with amphorae as related either to the crushing of aromatic substances added to wine (see Botto 2000 for Etruria, and Vives-Ferrándiz 2008: 255 for the eastern coast of the Iberian Peninsula). Furthermore, the miniaturization of amphorae, bowls and vases recorded in the caveshrines can be interpreted in a similar way; as other archaeological objects show, small pieces were used to store and keep precious or psychoactive materials, because the amount and the use of such substances were also quite limited (Guerra 2006: 371; López-Bertran 2007: 148-50).

Hearing would have been another sense that embodied the metaphorical journeys inside the caves. Caves have a tendency to echo, a phenomenon once considered to be supernatural; echoes are often interpreted as the voices of spirits answering human inquiries (Purser 2002: 28). In addition to the echo, most caves are highly resonant places where sound is amplified and carried (Lawson et al. 1998: 112). The sound of water may also have relaxed or hypnotized the audience (Strang 2005: 101). For these reasons, caves may be said to 'have agency' and could be considered as a musical instrument per se (Purser 2002: 28 and 33).

Many other sounds that would have created a ritual rhythm can be inferred from the material culture used in the caves, such as the vessels for cooking and eating. The large amounts of faunal remains found in both caves suggest that the inhabitants used to cook and eat fish inside the sanctuaries; such activities would have generated a range of special sounds like the crackle of fire, the cooking of the animals, the pounding of mortars and so on (López-Bertran and Garcia-Ventura 2008; Garcia-Ventura and López-Bertran 2009: 132).

The exploitation of smell, sight, taste and hearing would have created embodied rituals inside the caves, which themselves might be considered the starting point for otherworldly journeys. It is important to highlight the corporeal dimension for the achievement of these metaphoric movements. The bodily experiences in the rituals performed in the shrines underline the role of senses in archaeology. Smell, hearing and taste would have been exploited most during the rituals in Gorham's cave and Es Culleram. These senses are central elements in social activities and are essential in the various ways of creating and approaching specific contexts (Howes 2005; Classen 1993: 2; Hamilakis et al. 2002; Skeates 2010). 


\section{Uncovering Pilgrim Communities}

One of the problems that archaeologists face when studying rituals is the identification of different rites, and different people attending the same shrine, especially because the material culture involved is apparently the same (Kyriakidis 2007: 15). Whoever they were and wherever they came from, visitors used and performed similar practices like feasting, cremating and depositing votive offerings (López-Bertran 2007: 107-10).

Gorham's cave might be considered as a place that brought together different people from different settlements and with diverse interests and motivations, since it was an important reference point in creating cognitive maps, as well as shared perceptions and creations of the sea and the headlands. In this regard, people involved with the sea and navigation on a daily basis might well have shared similar views of the world and similar types of habitus, expressing them in their religious and symbolic beliefs (Ballard et al. 2003: 397; Cooney 2003: 324). Traditionally, it was thought that the rites performed in the caves were related to popular religion, but the presence of gold and silver jewels also suggests that elites may have taken part in the rituals performed there. I do not mean to say that there were no differences between Gorham's cave and other urban cult sites in the area, but rather to point out that the location of Gorham's cave in a non-urban area should not rule out the presence of elites.

In Es Culleram, Punic inhabitants from the whole island may have used the cave, especially those who inhabited the Sant Vicent valley. Its use by people from outside Ibiza seems unlikely, not only because of the distances involved but also because of the difficulty in identifying the cave from the sea. The remote location of the Sant Vicent valley, however, does not mean that the rituals in Es Culleram were marginal or performed by lower-status inhabitants, as indicated by the presence of two gold medallions in the cave and the nearby rock-cut tomb in Can
Pere Català (Fernández 1980). Located close to the beach, this tomb is the only one currently known in the Sant Vicent valley. Although it has not been systematically excavated, the grave goods were similar to those found in the urban cemetery of Puig des Molins in Ibiza town, and suggest the presence of high-ranking people in the valley with close connections to the main urban centre of the island (Gómez Bellard et al. 2005: 36; Gómez Bellard 2008: 61-62).

Motivations for visiting the shrines may have varied widely but the votive offerings suggest that they were mostly related to fertility in the broadest sense of the term: agricultural, maritime and human. Fertility is associated with cosmological cycles and the pilgrimages may therefore have been related closely to seasonal cycles, like the tide (in the Atlantic) or the beginning and ending of agricultural seasons, like harvests, as ethnographic evidence suggests (Cummings 2007: 56; Silverman 1994: 13; Coleman and Eade 2004: 13). The faunal remains from Es Culleram support this suggestion, as tooth marks show that the animals were sacrificed during the months of February and March. It has been suggested that these sacrifices would have celebrated the rebirth of nature at the end of winter and the beginning of spring (Costa 2007: 18). We can explore this issue further at Es Culleram if we consider the Demeter figurines in connection with women's visits to the shrine. It is conceivable that one of the groups attending the rituals involved women performing reproduction or fertility rites.

Despite the multiplicity of meanings and motivations associated with these sites, both Es Culleram and Gorham's cave can be considered as meeting places or nodal points in the landscape. By this, I do not mean that people with different motivations and origins would have met each other physically. Rather I would suggest that they shared a specific identity when they were there-perhaps a pilgrim's identity, because they performed the same rituals and activities: travelling there for a special purpose, performing the same activities like eating or 
drinking, and experiencing an embodied symbolic journey not only through their movement inside the caves but also through the transformation of their sensual perception. In short, they shared the same practices and, by implication, the same world view.

So can we consider the existence of the same practices as a way of creating a pilgrim community? Understanding communities as dynamic entities that are not rooted in space allows us to define the whole range of the visitors-from the inhabitants of the local settlements to the foreign seafarers who may have travelled here-as a community. Communities are created through the relationships between people and places; they play a part in cultural traditions and are symbolically constructed (Isbell 2000: 243-66; Gerritsen 2004: 141-54). Because of the importance of travelling for the Phoenicians and Punic peoples, visits to the cave-shrines would have participated in the creation of the landscape and seascape. Precisely because travelling is an essential feature of these cultures, this practice became ritualized through special journeys, through pilgrimages.

\section{Conclusion}

Considering pilgrimages as ritualized journeys and kinetic rituals is a fruitful approach that shows how ancient cases of mobility were not always motivated by economic or commercial considerations. Daily journeys were a way of constructing and maintaining identities and creating landscapes and seascapes in both everyday and ritual contexts. Highlighting the bodily and material dimension of movement inside the caves, moreover, is useful in attempting to understand how and to what extent pilgrimages are simultaneously physical and emotional actions. Physical movement thus also allows pilgrims to move metaphorically between worlds and states of consciousness, especially when entering the caves. Finally, the two cave-shrines examined here bear witness to different worldviews that were played out on pilgrimage and during rituals; at the same time they may also be interpreted as places of community where people do the same things and perceive landscapes and seascapes in similar ways.

\section{Acknowledgments}

A first draft of this article was written with the support of a DAAD (Deutsches Academic Austausch Dienst-German Academic Exchange Service) scholarship at the Eberhard-Karls Universität Tübingen (Germany) during the summer of 2010. I would like to thank the DAAD for their assistance and especially Professor Ingrid Gamer (Institut für Kulturen des Altes Orients) for supporting my proposal and accepting me as a research partner. I am also in debt to Agnès Garcia-Ventura and Jaime Vives-Ferrándiz for useful comments on earlier drafts of this paper and to Kimberly Brown (Gibraltar Museum) for providing me with pictures of Gorham caves. My final thanks go to the editors and referees of this journal, to Robin Skeates and especially to Nicholas Vella, who provided me with a copy of his unpublished $\mathrm{PhD}$ thesis. All their comments encouraged me to deal with some of the issues raised here in a more critical and nuanced way.

\section{About the author}

Mireia López-Bertran received her PhD degree in History from the Universitat Pompeu Fabra (Barcelona, Spain) in 2007 with a dissertation on Phoenician and Punic rituals in rural landscapes. From 2002-2006, she held a Research Fellowship from the Spanish Ministry of Education at the Universitat Pompeu Fabra. Her research interests include rituals, gender and embodiment in the ancient Western Mediterranean. She has been involved in the excavations of the University of Valencia in Lixus (Larache, Morocco) since 2005. Currently she is a postdoctoral researcher of the Spanish Ministry of Education and Culture-FECYT, and is working as an Honorary Research Fellow at the University of Glasgow. 


\section{References}

Aranegui, C. (ed.)

2005 Lixus 2. Ladera Sur. Excavaciones arqueológicas marroco-españolas en la colonia fenicia. Campañas 2000-2003. Saguntum Extra 6. Valencia: Universitat de València.

Aranegui, C., and H. Hassini (eds.)

2010 Lixus 3. Area suroeste del sector monumental. (Cámaras Montalban) 2005-2009. Saguntum Extra 8. Valencia: Universitat de València.

Aubet, M.E.

1982 El santuario d'Es Culleram. Treballs del Museu Arqueològic d'Eivissa i Formentera 8. Ibiza: Conselleria d'Educació i Cultura del Govern Balear.

2009 Tiro y las colonias fenicias de Occidente. Barcelona: Edicions Bellaterra.

Ballard, L., R. Bradley, L.N. Myhre and M. Wilson

2003 The ship as symbol in the prehistory of Scandinavia and South East Asia. World Archaeology 35: 385-403. doi:10.1080/0043824042000185784

Barroso, C.

1980 Nuevas pinturas rupestres en Jimena de la Frontera (Cádiz): Abrigo de la Laja Alta. Zephyrus 30-31: 23-45.

Belén, M.

2000 Itinerarios arqueológicos por la geografía sagrada del Extremo Occidente. In B. Costa and J.H. Fernández (eds.), Santuarios fenicio-púnicos en Iberia y su influencia en los cultos indigenas. XIV Jornadas de Arqueología Fenicio-Púnica: 57-102. Ibiza: Treballs del Museu Arqueològic d'Eivissa i Formentera.

Belén, M., and I. Pérez

2000 Gorham's Cave, un santuario en el estrecho: avance del estudio de los materiales cerámicos. In Actas del IV Congreso Internacional de Estudios Fenicios y Púnicos, 531-39. Cádiz: Universidad de Cádiz.

Bell, C.

1992 Ritual Theory, Ritual Practice. Oxford: Oxford University Press.

Bernal, D., and A.M. Sáez

2008 Fish-salting plants and amphorae production in the Bay of Cádiz (Baetica, Hispania): patterns of settlement from the Punic era to late Antiquity. In H. Vanhaverbeke, J. Poblome and F. Vermeulen (eds.), Thinking about Space: The Potential of Surface Survey and Contextual Analysis in the Definition of Space in Roman Times. Studies in
Eastern Mediterranean Archaeology 8: 45-113. Brepols: Leuven.

Blake, E.

2005 The material expression of cult, ritual and feasting. In E. Blake and A.B. Knapp (eds.), The Archaeology of Mediterranean Prehistory. Blackwell Studies in Global Archaeology 6: 102-29. Oxford: Blackwell. doi:10.1002/9780470773536.ch5

Botto, M.

2000 Tripodi siriani e tripodi fenici dal Latium Vetus e dall'Etruria meridionale. In P. Bartoloni and L. Campanella (eds.), La ceramica fenicia di Sardegna: Dati, problematiche, confronti. Atti del Primo Congresso Internazionale Sulcitano, 63-98. Rome: Consiglio Nazionale delle Ricerche.

Bourdieu, P.

1977 Outline of a Theory of Practice. Cambridge: Cambridge University Press.

Bradley, R.

2002 An Archaeology of Natural Places. London: Routledge.

2005 Ritual and Domestic Life in Prehistoric Europe. London: Routledge.

Brody, A. J.

1998 'Each Man Cried out to his God': The Specialized Religion of Canaanite and Phoenician Seafarers. Harvard Semitic Monographs 58. Atlanta: Scholars Press.

Brück, J.

1999 Ritual and rationality: some problems of interpretation in European archaeology. European Journal of Archaeology 2: 313-34. doi:10.1177/ 146195719900200303

Candy, J.

2009 The Archaeology of Pilgrimage on the Camino de Santiago de Compostella: A Landscape Perspective. British Archaeological Reports International Series 1948. Oxford: Archaeopress.

Classen, C.

1993 Worlds of Sense: Exploring the Senses in History and across Cultures. London: Routledge.

Coleman, S.

2002 Do you believe in pilgrimage? Communitas, contestation and beyond. Anthropological Theory 2: 355-68. doi:10.1177/1463499602002003805

Coleman, S., and J. Eade

2004 Introduction: reframing pilgrimage. In S. Coleman and J. Eade (eds.), Reframing Pilgrimage: Cultures in Motion, 1-25. London: Routledge. 
Cooney, G.

2003 Introduction: seeing land from the sea. World Archaeology 35: 323-28. doi:10.1080/ 0043824042000185748

Costa, B.

2007 Es Culleram. 100 anys/años. Ibiza: Museu Arqueològic d'Eivissa i Formentera.

Costa, B., and J.H. Fernández (eds.)

1998 Rutas, navios y puertos fenicio-púnicos. XI Jornadas de Arqueología Fenicio-Púnica. Ibiza: Treballs del Museu Arqueològic d'Eivissa i Formentera.

Culican, W.

1972 Phoenician remains from Gibraltar. Australian Journal of Biblical Archaeology 1(5): 110-45.

Cummings, V.

2007 Megalithic journeys: moving around the monumental landscapes of the Neolithic western Britain. In V. Cummings and R. Johnston (eds.), Prehistoric Journeys, 54-63. Oxford: Oxbow.

Cummings, V., and R. Johnston

2007 Leaving place: an introduction to Prehistoric Journeys. In V. Cummings and R. Johnston (eds.), Prehistoric Journeys, 1-7. Oxford: Oxbow.

Delgado, A.

2008 Fenicios en Iberia. In F. Gracia Alonso (ed.), De Iberia a Hispania, 347-474. Barcelona: Ariel.

Escacena, J.L., A. Fernández and A. Rodríguez

2007 Sobre el Carambolo: un hippos sagrado del santuario IV y su contexto arqueológico. Archivo Español de Arqueología 80: 5-27.

Fantar, M.H.

1977 Le dieu de la mer chez les pheniciens et les puniques. Studi Semitici 48. Rome: Consiglio Nazionale delle Ricerche.

Fernández, J.H

1980 El hipogeo de Sant Pere Catalá des Port (Sant Vicent de Sa Cala). Treballs del Museu Arqueològic d'Eivissa i Formentera 4. Ibiza: Conselleria d'Educació i Cultura del Govern Balear.

Garcia-Ventura, A., and M. López-Bertran

2009 Embodying musical performances in the ancient Mediterranean. Archeomusicological Review of the Ancient Near East 1: 39-45.

Gerritsen, F.

2004 Archaeological perspectives on local communities. In J. Bintliff (ed.), A Companion to Archaeology, 141-54. Oxford: Blackwell.
Gibson, E.

2007 The archaeology of movement in a Mediterranean landscape. Journal of Mediterranean Archaeology 20: 61-87.

Gómez Bellard, C.

2008 Ibiza: the making of new landscapes. In P. van Dommelen and C. Gómez Bellard (eds.), Rural Landscapes of the Punic World. Monographs in Mediterranean Archaeology 11: 44-75. London: Equinox.

Gómez Bellard, C., and P. Vidal González

2000 Las cuevas-santuario fenicio-púnicas y la navegación en el Mediterráneo. In B. Costa and J.H. Fernández (eds.), Santuarios fenicio-púnicos en Iberia y su Influencia en los Cultos indígenas. XIV Jornadas de Arqueología fenicio-púnica: 103-46. Ibiza: Treballs del Museu Arqueològic d'Eivissa i Formentera.

Gómez Bellard, C., V. Marí and R. M. Puig Moragón

2005 Evolución del poblamiento rural en NE de Ibiza en época púnica y romana (prospecciones sistemáticas 2001-2003). Saguntum 35: 27-43.

Guerra, E.

2006 Las drogas en la Prehistoria: Evidencias arqueológicas del consumo de sustancias psicoactivas en Europa. Barcelona: Edicions Bellaterra.

Guerrero Ayuso, V.

2008 Las naves de Kerné II: Navegando por el Atlántico durante la protohistoria y la antigüedad. In R. Gonzalez Antón, F. López Pardo and V. Peña (eds.), Los Fenicios y el Atlántico, 69-142. IV Coloquio del CEFYP. Madrid: Universidad Complutense de Madrid.

Gutiérrez López, J.M., M.C. Reinoso del Río, F. Giles Pacheco and C. Finlayson

2001 Nuevos estudios sobre el santuario de Gorham's Cave (Gibraltar). Almoraima 25: 13-30.

Hamilakis Y., M. Pluciennik and S. Tarlow (eds.)

2002 Thinking through the Body: Archaeologies of Corporeality. New York: Kluwer Academic/Plenum Publishers.

Helms, M.W.

1988 Ulysses' Sail: An Ethnographic Odyssey of Power, Knowledge and Geographical Distance. Princeton: Princeton University Press.

Hours-Médian, M.

1951 Les represéntations figurées sur les steles de Carthage. Cahiers de Byrsa 1. Paris: Imprimerie Nationale. 
Howes, D.

2005 Introduction: empire of senses. In D. Howes (ed.), Empire of the Senses: The Sensual Culture Reader, 1-19. Oxford: Oxford University Press.

Ingold, $\mathrm{T}$.

2000 The Perception of the Environment: Essays in Livelihood, Dwelling and Skill. London: Routledge. doi:10.4324/9780203466025

2004 Culture on the ground: the world perceived through feet. Journal of Material Culture 9: 31540. doi:10.1177/1359183504046896

Inomata, T., and S.L. Coben

2006 Overture: an invitation to the archaeological theater. In T. Inomata and S.L. Coben (eds.), Archaeology of Performance: Theaters of Power, Community and Politics, 11-44. Lanham, MD: Altamira Press.

Insoll, T.

2004 Archaeology, Ritual and Religion. London: Routledge.

Isbell, W.

2000 What we should be studying: the 'imagined community' and the 'natural community'. In M. Canuto and J.Yaeger (eds.), The Archaeology of Communities: A New World Perspective, 24366. London: Routledge.

Kador, T.

2007 Stone Age motion pictures: an object's perspective from early Prehistoric Ireland. In V. Cummings and R. Johnston (eds.), Prehistoric Journeys, 33-44. Oxford: Oxbow.

Knapp, A.B., and P. van Dommelen

2010 Material connections: mobility, materiality and Mediterranean identities. In P. van Dommelen and A.B. Knapp (eds.), Material Connections in the Ancient Mediterranean: Mobility, Materiality and Identity, 1-18. London: Routledge.

Kyriakidis, E.

2007 Finding ritual: calibrating the evidence. In E. Kyriakidis (ed.), The Archaeology of Ritual. Cotsen Advanced Seminar 3: 9-22. Los Angeles: Cotsen Institute of Archaeology, UCLA.

Lawson, G., C. Scarre, I. Cross and C. Hills

1998 Mounds, megaliths, music and mind: some thoughts on the acoustical properties and purposes of archaeological spaces. Archaeological Review from Cambridge 15: 111-34.

López de la Orden, M.D.

1995 Los escarabeos de Gorham’s cave: su iconografía.
In Actas del II Congreso Internacional 'El Estrecho de Gibraltar', 119-27. Madrid: Universidad Nacional de Educación a Distancia.

López -Bertran, M.

2007 Ritualizando cuerpos y paisajes: un análisis antropológico de los rituales fenicio-púnicos. Unpublished $\mathrm{PhD}$ dissertation, Universidad Pompeu Fabra, Barcelona. Internet Edition: http://www.tesisenred.net/TDX-0513108170353.

López-Bertran, M., and A. Garcia-Ventura

2008 Materializing music and sound in some Phoenician and Punic contexts. Saguntum 40: 27-36.

López-Bertran, M., A. Garcia-Ventura and M. Krueger

2008 Could you take a picture of my boat please? The use and significance of Mediterranean ship representations. Oxford Journal of Archaeology 27: 341-57. doi:10.1111/j.14680092.2008.00312.x

McNiven, I.J.

2003 Saltwater people: spiritscapes, maritime rituals and the archaeology of Australian indigenous seascapes. World Archaeology 35: 329-49. doi:10.1080/0043824042000185757

Medas, S.

1998 Siderum observationem in navigando Phoenicies (invenerunt) (Plinio, N. H. VII, 209). Appunti di navigazione astronomica. Rivista di Studi Fenici 26: 147-73.

2000 La marineria cartaginese: le navi, gli uomini, le navigazione. Sassari: Carlo Delfino.

Meskell, L., and R.M. Joyce

2003 Embodied Lives: Figuring Ancient Maya and Egyptian Experience. London: Routledge.

Mitchell, J.P.

2006 Performance. In C. Tilley, W. Keane, S. Kuechler-Fogden, M. Rowlands and P. Spyer (eds.), Handbook of Material Culture, 384-401. London: Sage.

Morales Pérez, J.V.

2003 Estudio de la fauna de la cueva-santuario púnica de Es Culleram (Sant Joan, Eivissa). Saguntum 35: 113-22.

Morinis, A.

1992 Introduction: the territory of the anthropology of pilgrimage. In A. Morinis (ed.), Sacred Journeys: The Anthropology of Pilgrimages, 1-28. London: Greenwood Press. 
Peña, V. (ed.)

2004 La navegación fenicia. Tecnología naval y derroteros. Encuentro entre marinos, arqueólogos e historiadores. Madrid: Centro de Estudios Fenicios y Púnicos.

Posadas, J.L.

1988 Amuletos y divinidades egipcias en el Estrecho de Gibraltar preromano. Nueva valoración de su influencia religiosa en el medio colonial. In Actas del Congreso Internacional El Estrecho de Gibraltar I, 517-27. Madrid: Universidad Nacional de Educación a Distancia.

Purser, J.

2002 The womb of sound. In E. Hickmann, A.D. Kilmer and R. Eichmann (eds.), Studien zur Musikarchäologie III, 39-53. Berlin: Marie Leidorf.

Ramón, J.

1985 Es Culleram, 1981. Noticiario Arqueológico Hispánico 20: 225-56.

Roldán Gómez, L., M. Bendala Galán, J. Blánquez Pérez and S. Martínez Lillo (eds.)

2006 Estudio histórico-arqueológico de Carteia (San Roque, Cádiz) 1994-1999. Arqueología Monografías. Sevilla: Junta de Andalucía.

Romero Recio, M.

2000 Cultos maritimos y religiosidad de navegantes en el mundo griego antiguo. British Archaeological Reports International Series 897. Oxford: Archaeopress.

Ruiz-Gálvez, M.

2005 Representaciones de barcos en el arte rupestre: piratas y comerciantes en el tránsito de la edad del bronce a la edad del hierro. Mayurqa 30: 307-39.

Schubart, $\mathrm{H}$.

1987 Hallazgos fenicios y del Bronce Final en la desembocadura del río Guadiaro (Cádiz). Anuario Arqueológico de Andalucía 2: 200-27.

Sherratt, A.

1991 Sacred and profane substance: the ritual use of narcotics in later Neolithic Europe. In P. Garwood, R. Jennings, R. Skeates and J. Toms (eds.), Sacred and Profane: Proceedings of a Conference on Archaeology, Ritual and Religion, 50-64. Oxford: Oxbow.

Silverman, $\mathrm{H}$.

1994 The Archaeological Identification of an Ancient Peruvian Pilgrimage Center. World Archaeology 26: 1-18. doi:10.1080/00438243.1994.9980257
Skeates, S.

2007 Religious experience in the prehistoric Maltese underworld. In D.A. Barrowclough and C. Malone (eds.), Cult in Context: Reconsidering Ritual in Archaeology, 90-96. Oxford: Oxbow.

2010 An Archaeology of the Senses: Prehistoric Malta. Oxford: Oxford University Press.

Slavin, S.

2003 Walking as spiritual practice: the pilgrimage to Santiago de Compostela. Body and Society 9(3): 1-18. doi:10.1177/1357034X030093001

Strang, V.

2005 Common senses, water, sensory experience and the generation of meaning. Journal of Material Culture 10: 92-120. doi:10.1177/1359183505050096

Taçon, P.

1994 Socialising landscapes: the long-term implications of signs, symbols and marks on the land. World Archaeology 29: 117-29.

Tilley, C.

2004 The Materiality of the Stone: Explorations in Landscape Phenomenology. Oxford: Berg.

Vella, N.

1998 Ritual, Landscape and Territory: Phoenician and Punic non-Funerary Religious sites in the Mediterranean: An Analysis of the Archaeological Evidence. Unpublished PhD Dissertation, University of Bristol, UK.

2005 A maritime perspective: looking for Hermes in an ancient seascape. In J. Chrysostomides, C. Dendrinos and J. Harris (eds.), The Greek Islands and the Sea, 33-57. Camberley: Prophyrogenitus.

Villada, F., J. Ramón and I. Suárez Padilla

2007 Nuevos datos en torno a los inicios del poblamiento de la ciudad de Ceuta: avance preliminar de la excavación de la plaza de la Catedral. Akros. Revista de Arqueología e Historia de Melilla 6: 125-34.

Vives-Ferrándiz, J.

2008 Negotiating colonial encounters: hybrid practices and consumption in eastern Iberia (8th-6th centuries вс). Journal of Mediterranean Archaeology 21: 241-72.

Waechter, J.

1951 Excavations at Gorham's Cave, Gibraltar: preliminary report for the seasons 1948-1950. Proceedings of the Prehistoric Society 17: 83-92.

1953 The excavation at Gorham's Cave and its relations

(C) The Fund for Mediterranean Archaeology/Equinox Publishing Ltd., 2011

\section{eevinoxonline}


to the prehistory of southern Spain. Archivo de Prehistoria Levantina 4: 21-40.

Whitehouse, R.

1992 Underground Religion: Cult and Culture in Prehistoric Italy. Accordia Specialist Studies on Italy 1. London: Accordia Research Centre.
2007 Underground religion revisited. In D.A. Barrowclough and C. Malone (eds.), Cult in Context: Reconsidering Ritual in Archaeology, 97-106. Oxford: Oxbow.

\section{equinoxonline}

